\title{
アゾ系分散染料の異常光退色におよぼすニトロ基の寄与 ${ }^{122}$
}

\author{
(1973 年 9 月 4 日 受 理)
}

北尾悌次郎・和多田幸夫・松 岡 蜸・小西謙 三*

ニトロ基を有する三三のアゾ系分散染料の光退色挙動がポリエステルおよびポリアミドフィルム上で 調ベられた。そしてこれら染料の異常退色に抽よぽすニトロ基の寄与が検討考察された。アソ系分散染 料の耐光性は光酸化のらけやすさとキノンヒドラン゙ン構造の寄与によって決まるので電子吸引性基の導 入は耐光性を向上させることになっている。ところがニトロ基を有する染料ではこれに矛盾して特異的 に耐光性が低下する異常現象を示寸場合がある。4-ニトロアソベンゼン系染料の異常退色はポリアミド 上にみられる基質特異性現象であって, 染料の塩基性度と異常退色のらけやすさとの間にはある関係が みられる。すなわち，カップリング成分の電子供与力が小さいほど，またはシフソ成分の電子吸引力が 大きいほど異常退色をうけやすく，ここではさきの機構に髟先するニトロ基の光還元の寄与が示唆され る。一方，2-ニトロアゾベンゼン系染料の異常退色は基質には関係なくみられる位置特異性現象であっ て，积気条件下でもその退色举動は変わらない。ここでは によるアゾキシ化の寄与が示唆される。また，2,4-ジニトロアゾベンゼン系染料の退色挙動についても 検討考察した。

\section{1 緒言}

染料の光退色通程は染料の化学構造のみならず，染料の染着状 態，基質の性質，外的条件，共存物質の性質など多くの因子によ って決定される非常に袮雑な系であるとされている。このらち染 料の化学構造之耐光性との関係については, 以前から数多くの経 験的事実が集䅡されており，著者らもさきにアン゙系分散染料の 光退色挙動をナイロンとポリエステルフィルム上に扎いて検討考 察した。これによると、アソ系分散染料の光退色過程はまずフソ 基のアソキシ基への光酸化にはじまり，光 Wallach 転位をうけ て ○ーヒドロキシアソ語䢙体を生成し，ついでそのキノンヒドラソ ン棈造の光加井分解を経て進行するといら機構が妥当なよらであ る。したがって，あるアソ染料の耐光性は光酸化のらけやすさと キノンヒドラソン棈造の奇与の大きさによって決まるので, 電子 供与性基の道入は耐光性を低下し，電子吸引性基俚耐光性を向上 させるとい方る。ところがニト口基を有する染料系では，この機 棈に矛看して，特異的に耐光性が低下寸るといら異常退色現象を 亦す場合がある。たとえば，4-ニトロー4'-(N-エチルーN-シア） エチル)アミノー1, 1'-フソベンゼンのフソ基のオルト位にある $\mathrm{R}$ 睓換基のポリエステル上における耐光性に扰よぼす影響をみる と，二トロ基を除き，電子吸引性基を尊入すると日光堅口ウ度が 向上 $(\mathrm{R}=\mathrm{H} 5$ 級， $\mathrm{Cl} 6$ 級， $\mathrm{CN} 6 \sim 7$ 級）し，供与性基を入れる と日光堅口ウ度の低下 $\left(\mathrm{R}=\mathrm{CH}_{3} 4 \sim 5\right.$ 級, $\mathrm{OCH}_{3} 3 \sim 4$ 級) が認め

1）この報文を“染料の光退色機構飞関する研究(第 4 報)” する。

2）前報（第 3 報），梅本弘俊，和多田幸夫，福岛四郎，松岡 堅，北尾悌次郎，小西澓三，工化，74，2333(1971).

* 大阪府立大学工学部応用化学数室, 591 堺市百舌鳥梅町

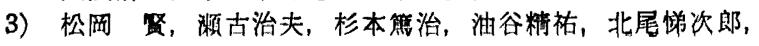
小西渺三，工化，74，1655(1971).
られ，さきの機構に矛盾しないけれどあ：ニトロ基の場合には異 常に退色しやすい $\left(\mathrm{R}=\mathrm{NO}_{2} 2 \text { 級 }\right)^{4)}$ 。また，同じ染料によるナイ ロン上に括ける日光堅ロウ度はニトロ基（1 級）を除き, ポリェ ステル上の結果とはまったく逆 $\left(^{\left(\mathrm{OCH}_{3} 4\right.}\right.$ 級, $\mathrm{CH}_{3} 4 \sim 5$ 級, $\mathrm{H} 4$

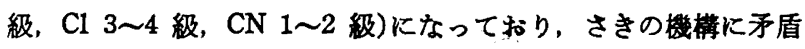
した異常退色を示すことが知られている4)。このように，ニトロ 基の導入は本来なら，その系染料の耐光性を向上させるはずであ るにもかかわらず， のオルト位といら特定位置にニトロ基があると,ポリェステルと ポリアミドの基質を問わず特翼的に退色しやすくなるので著者ら は位膡特異性の異常退色現象と考えた。これに対して, $p$-ニトロ フェニルアゾ系染料のよらにポリェステル上では正常退色を示す がポリアミド上でのみ特異的に退色しやすくなる搏合には基質特 異性の異常退色現象と考えた。

そこでこれら異常退色現象を検討するアブローチモデルに2ニトロアゾペンゼン系, 4-ニトロアソペンゼン系および 2,4-ジニ トロアソベンゼン系染料を選び, ポリアミドとボリエステルフィ ルム上に怙ける光退色挙動におよぼすニト口基の寄与を考察した。 なお、ここでは，できるだけ同一条件下における密接な構造関 係にある染料間の退色の目安として, 既報采) と同様, 固有退色值 を用いた。

\section{2 実誤}

\section{1 供漹染料の合成}

供試番号 1〜8 の染料は松岡ら の方法にしたがって合成した。 また，供試番号 9〜28のものは常法に準して合成し、元来分析 によって確認した。その結果を表 1 に示す。

\section{2 染色}

4) C. Müller, Amer. Dyestuff Rep̣t., 59, (3), 37(1970). 
Table 1 Nitroazobenzene derivatives

\begin{tabular}{|c|c|c|c|c|c|}
\hline \multirow{2}{*}{$\begin{array}{c}\text { Compd. } \\
\text { No. }\end{array}$} & \multirow{2}{*}{$\begin{array}{l}\mathrm{mp}^{a)} \\
\left({ }^{\circ} \mathrm{C}\right)\end{array}$} & \multicolumn{4}{|c|}{ Analysis $(\%)$} \\
\hline & & \multicolumn{2}{|c|}{ Calcd. } & \multicolumn{2}{|c|}{ Found } \\
\hline \multirow{4}{*}{9} & & $\mathrm{C}$ & 75.85 & $\mathrm{C}$ & 76.49 \\
\hline & $100 \sim 101^{\mathrm{a}}$ & $\mathrm{H}$ & 7.56 & $\mathrm{H}$ & 7.83 \\
\hline & & $\mathrm{N}$ & 16.59 & $\mathrm{~N}$ & 17.20 \\
\hline & & $\mathrm{C}$ & 64.41 & $\mathrm{C}$ & 64.60 \\
\hline \multirow[t]{3}{*}{10} & $151 \sim 152^{\mathrm{s}}$ & $\mathrm{H}$ & 6.08 & $\mathrm{H}$ & 6.17 \\
\hline & & $\mathrm{N}$ & 18.78 & $\mathrm{~N}$ & 19.24 \\
\hline & & $\mathrm{C}$ & 62.07 & $\mathrm{C}$ & 62.87 \\
\hline \multirow[t]{3}{*}{11} & $156 \sim 158^{b}$ & $\mathrm{H}$ & 4.60 & $\mathrm{H}$ & 4.63 \\
\hline & & $\mathrm{N}$ & 24.14 & $\mathrm{~N}$ & 23.90 \\
\hline & & $\mathrm{C}$ & 62.07 & $\mathrm{C}$ & 61.62 \\
\hline \multirow[t]{3}{*}{12} & $204 \sim 206^{b}$ & $\mathrm{H}$ & 4.60 & $\mathrm{H}$ & 4.44 \\
\hline & & $\mathrm{N}$ & 24.14 & $\mathrm{~N}$ & 26.63 \\
\hline & & $\mathrm{C}$ & 63.14 & $\mathrm{C}$ & 63.30 \\
\hline \multirow[t]{3}{*}{13} & $106 \sim 108^{8}$ & $\mathrm{H}$ & 5.30 & $\mathrm{H}$ & 5.27 \\
\hline & & $\mathrm{N}$ & 21.66 & $\mathrm{~N}$ & 21.83 \\
\hline & & $\mathrm{C}$ & 63.14 & $\mathrm{C}$ & 63.31 \\
\hline \multirow[t]{3}{*}{14} & $173 \sim 174^{b}$ & $\mathrm{H}$ & 5.30 & $\mathrm{H}$ & 5.25 \\
\hline & & $\mathrm{N}$ & 21.66 & $\mathrm{~N}$ & 21.74 \\
\hline & & $\mathrm{C}$ & 58.18 & $\mathrm{C}$ & 58.11 \\
\hline \multirow[t]{3}{*}{15} & $134 \sim 136^{b}$ & $\mathrm{H}$ & 5.45 & $\mathrm{H}$ & 5.46 \\
\hline & & $\mathrm{N}$ & 16.97 & $\mathrm{~N}$ & 17.66 \\
\hline & & $\mathrm{C}$ & 58.18 & $\mathrm{C}$ & 58.26 \\
\hline \multirow[t]{3}{*}{16} & $204 \sim 206^{b}$ & $\mathrm{H}$ & 5.45 & $\mathrm{H}$ & 5.49 \\
\hline & & $\mathrm{N}$ & 16.97 & $\mathrm{~N}$ & 16.78 \\
\hline & & $\mathrm{C}$ & 64.41 & $\mathrm{C}$ & 65.13 \\
\hline \multirow[t]{3}{*}{17} & $110 \sim 111$ & $\mathrm{H}$ & 6.08 & $\mathrm{H}$ & 6.06 \\
\hline & & $\mathrm{N}$ & 18.78 & $\mathrm{~N}$ & 18.80 \\
\hline & & C & 55.97 & $\mathrm{C}$ & 56.41 \\
\hline \multirow[t]{3}{*}{19} & $166 \sim 167^{\circ}$ & $\mathrm{H}$ & 4.99 & $\mathrm{H}$ & 4.93 \\
\hline & & $\mathrm{N}$ & 20.40 & $\mathrm{~N}$ & 20.36 \\
\hline & & $\mathrm{C}$ & 45.50 & $\mathrm{C}$ & 45.65 \\
\hline \multirow[t]{3}{*}{20} & $190 \sim 191^{2}$ & $\mathrm{H}$ & 3.79 & $\mathrm{H}$ & 3.72 \\
\hline & & $\mathbf{N}$ & 16.59 & $\mathrm{~N}$ & 16.20 \\
\hline & & C & 63.14 & C & 62.80 \\
\hline \multirow[t]{3}{*}{21} & $165 \sim 166^{\circ}$ & $\mathrm{H}$ & 5.30 & $\mathrm{H}$ & 5.47 \\
\hline & & $\mathrm{N}$ & 21.66 & $\mathrm{~N}$ & 21.00 \\
\hline & & $\mathrm{C}$ & 55.43 & C & 55.50 \\
\hline 22 & $137 \sim 139^{\mathrm{a}}$ & $\mathrm{H}$ & 4.35 & $\mathrm{H}$ & 4.29 \\
\hline & & $\mathrm{N}$ & 22.83 & $\mathrm{~N}$ & 22.65 \\
\hline & & $\mathrm{C}$ & 45.64 & $\mathrm{C}$ & 45.27 \\
\hline 23 & $187 \sim 189^{\circ}$ & $\mathrm{H}$ & 3.36 & $\mathrm{H}$ & 3.14 \\
\hline & & $\mathrm{N}$ & 18.79 & $\mathrm{~N}$ & 17.97 \\
\hline & & $\mathrm{C}$ & 62.07 & $\mathrm{C}$ & 61.82 \\
\hline 24 & $154 \sim 155^{2}$ & $\mathrm{H}$ & 4.60 & $\mathrm{H}$ & 4.50 \\
\hline & & $\mathrm{N}$ & 24.14 & $\mathrm{~N}$ & 23.78 \\
\hline & & $\mathrm{C}$ & 60.18 & $\mathrm{C}$ & 60.01 \\
\hline 25 & $169 \sim 172^{\circ}$ & $\mathrm{H}$ & 5.05 & $\mathrm{H}$ & 4.04 \\
\hline & & $\mathrm{N}$ & 20.65 & $\mathrm{~N}$ & 20.13 \\
\hline & & $\mathrm{C}$ & 53.13 & C & 52.02 \\
\hline 26 & $105 \sim 107^{\circ}$ & $\mathrm{H}$ & 4.17 & $\mathrm{H}$ & 3. 92 \\
\hline & & $\mathbf{N}$ & 20.88 & $\mathrm{~N}$ & 21.09 \\
\hline & & C & 44.06 & $\mathrm{C}$ & 43.56 \\
\hline 27 & $167 \sim 169^{c}$ & $\mathrm{H}$ & 3.24 & $\mathrm{H}$ & 3.08 \\
\hline & & $\mathbf{N}$ & 18.14 & $\mathrm{~N}$ & 16. 97 \\
\hline & & $\mathrm{C}$ & 59.34 & C & 58.53 \\
\hline 28 & $127 \sim 129^{\circ}$ & $\mathrm{H}$ & 4.40 & $\mathrm{H}$ & 4.21 \\
\hline & & $N$ & 23.08 & $\mathrm{~N}$ & 22.78 \\
\hline
\end{tabular}

a) Recrystallized from a (aceton), b (DMF) or c (methanol).

基貿フィルムには二軸延伸ボリエステルフィルム（三蕧樹脂， ,Q25 mm) と無延伸ナイロン-6 フィルム (東レ, $0.020 \mathrm{~mm}$ ) を
用い，いずれも前処理をせずに染色に供した。

染浴は既報23) と同様分散剂を加えて調製し，浴比は $500: 1$ (ナ イロン）または 250:1(ポリエステル) とした。ナイロンフィル ムの染色には $100^{\circ} \mathrm{C}$, ポリエステルフィルムの染色には $130^{\circ} \mathrm{C} て ゙$ それぞれ1〜3 時間を要した。染色フィルムは蒸留水で洗淨後， 畭燥し、染料を含まない溶液で同一処理したフィルムを標淮とし て，比色定量を行なった。

\section{3 固有退色值}

フィルム上に括勀る各染料の比色定䡒には分光光度計，光照射 飞はカーボンフーク灯を既報289) と同様に用い, フィルム上の

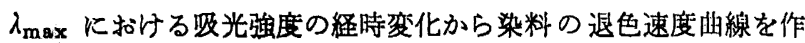
成し，この勾配から染料の同一時間带（主として0〜5 時間，た だし，No.11〜18 のポリエステル上と，No.11 と 12 のナイロ

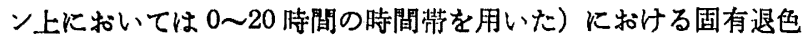
值を求めた。また，嫌気条件下の試料はフィルムを高真空用シリ コンクリースでューティングし，石英がラス板にはさんでセロテ ープで固定し，脱気してから則面をシリコングリースで扰括っ た。

\section{3 結果および考寮}

異常退色飞乱ける基質特異性現象を検討するため，まず4-二ト

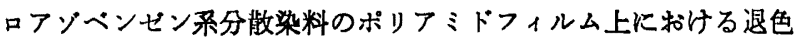
举動を調べた。この結果を表 2 亿示す。これによると，2'ーヒド

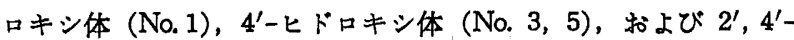
ジドロキシ体 (No.7) のいずれの系列化おいてす，4-位沉=ト 口基を導入すると未置換体化くらへ耐光性の低下することか認め られる。しかも極大吸収波畏が赫色移動する汪ど，つまりカップ リンク成分の奄子供与性力が增すほど退色加速奻果（その系に二 ト口基を導入することによる退色速度增大の割合）の程度（ここ で，5.3，4.6，3.2，1.2）が減少している。そして，4'-ジメチ ルフミノ体 (No.9）ではニト口基岁通入することによって正常に 耐光性が向上し,ここではもは中異常退色はみられない。このこ とはポリアミドフィルム上に批りるトロ基の光還元反応の起こ りやすさに対応しているよらに思われる。つまりニト口基の還元 はその電子密度の城少する活ど有利になるはずであるからカップ リンク成分の䉓子供与力が增すほど還元反応が抑制されるわけで ある。事帮, 4-ニトロ-4'-(N-エチルーN-シアノェチル)アミノ -1 , 1'ーアソベンゼン（No. 14）でる同核な異常退色現象がみられな いか，これら（No.14 と9）飞2-位㯰换基としてクロル4)やシア ンを導入したり (No. 21 と 24), 4-ニトロ-4'-( $N, N$-ビスシフ ノェチル)アミノ-1,1'-アゾベンゼン（No.12）ではポリアミト上 に和ける基質特異性の異常退色現象がみられる。それからちなみ に二トロ基が光還元を5ける例性かなり多い。たと之ば，二トロ

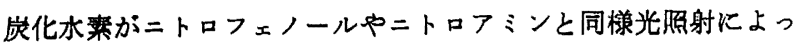
て着色すること，m-ジニトロベンゼンの光照射によって単離さ れた褐色生成物はアジキシ化合物であること, Naphthol Yellow S の光照射では 2-位二ト口基は分子内水絜結合の寄与によって 保持されるけれども4-位二ト口期は還元されてアミ/基飞変わ ることなどが知られているす。したがって，ある種の4-ニトロフ ェニルアゾ系分散染料の異常退色徒ポリアミト上にみられる基質

5) G.S.Egerton, A. G. Morgan, J. Soc, Dyers Çol., 86, 242(1970), 
Table 2 Fading parameter for some 4-nitroazobenzenes in polyamide film

\begin{tabular}{|c|c|c|c|c|c|c|}
\hline No. & Compounds & $\mathrm{X}$ & $\begin{array}{c}\lambda_{\max } \\
(\mathrm{nm})\end{array}$ & $\begin{array}{c}\varepsilon_{\max } \\
\left(\times 10^{-4}\right)\end{array}$ & $\begin{array}{r}\left.\mathrm{SFC}^{a}\right) \\
\left(10^{3} / \mathrm{hr}\right)\end{array}$ & $\begin{array}{c}\mathrm{RSF}^{(\mathbf{b}} \\
(\mathrm{X} ; \mathrm{H}=1)\end{array}$ \\
\hline 1 & & $\mathrm{H}$ & 335 & 2.18 & 6.98 & 1.0 \\
\hline 2 & & $\mathrm{NO}_{2}$ & 355 & 2.22 & 36.9 & 5.3 \\
\hline 3 & & $\mathrm{CH}_{3}$ & 354 & 2.67 & 1.09 & 1.0 \\
\hline 4 & & $\mathrm{NO}_{2}$ & 383 & 2.55 & 5.03 & 4.6 \\
\hline 5 & & $\mathrm{H}$ & 357 & 2.34 & 2.81 & 1.0 \\
\hline 6 & & $\mathrm{NO}_{2}$ & 398 & 2.37 & 8.95 & 3.2 \\
\hline 7 & & $\mathrm{H}$ & 387 & 2.40 & 58.6 & 1.0 \\
\hline 8 & & $\mathrm{NO}_{2}$ & 443 & 2.89 & 73.3 & 1.2 \\
\hline 9 & & $\mathrm{H}$ & 417 & 3.17 & 10.0 & 1.0 \\
\hline 10 & & $\mathrm{NO}_{2}$ & 490 & 3.76 & 7.6 & 0.76 \\
\hline
\end{tabular}

a) Specific fading const. is defined as $-\mathrm{d} c / \mathrm{d} t / C_{0}$.

b) Relative specific fading const.

Table 3 Fading perameter for some 4- and 2-nitroazobenzenes in PE and PA film

\begin{tabular}{|c|c|c|c|c|c|c|c|c|c|c|}
\hline \multirow[b]{2}{*}{ No. } & \multirow{2}{*}{\multicolumn{2}{|c|}{ Compounds }} & \multirow[b]{2}{*}{$\begin{array}{l}\lambda_{\max } \\
(\mathrm{nm})\end{array}$} & \multirow[b]{2}{*}{$\left(\times 10^{-4}\right)$} & \multicolumn{3}{|c|}{ Polyester } & \multicolumn{3}{|c|}{ Polyamide } \\
\hline & & & & & $\left.C_{0}{ }^{a}\right)$ & $\underset{\left(10^{8} / \mathrm{hr}\right)}{\mathrm{SFS}}$ & $\begin{array}{l}\text { RSF } \\
(0 / P)\end{array}$ & $\left.C_{0}{ }^{a}\right)$ & $\underset{\left(10^{8} / \mathrm{hr}\right)}{\mathrm{SFC}}$ & $\begin{array}{l}\text { RSF } \\
(0 / P)\end{array}$ \\
\hline 11 & & $0-$ & 412 & 2.75 & 0.9 & 31.5 & & 0.5 & 42.5 & \\
\hline 12 & & $p-$ & 435 & 2. 60 & 1.5 & 4.6 & 6.8 & 0.3 & 30.3 & 1.4 \\
\hline 13 & & $0-$ & 426 & 2.90 & 1.2 & 27.0 & & 1.2 & 35.7 & \\
\hline 14 & & $p-$ & 457 & 3.43 & 1.5 & 3.8 & 7 & 0.4 & 3.4 & 10 \\
\hline 15 & & $0-$ & 440 & 3.07 & 1.0 & 37.7 & & 0.9 & 34.7 & \\
\hline 16 & & $p-$ & 478 & 3. 42 & 1.0 & 13. 7 & 2.8 & 1.1 & 4.0 & 8.7 \\
\hline 16 & & $0-$ & 455 & 3.00 & 1.8 & 19.2 & & 0.7 & 38 & \\
\hline 18 & & $p-$ & 490 & 3.76 & 1.7 & 4.4 & 4.4 & 0.5 & 7.6 & 5.0 \\
\hline
\end{tabular}

a) Intial optical density of dye on film.

Table 4 Fading parameter for some 4- and 2-nitroazobenzenes on PE film in anaerobic condition

\begin{tabular}{|c|c|c|c|c|c|c|c|c|c|}
\hline \multirow[b]{2}{*}{ No. } & \multirow[b]{2}{*}{ Compound } & & \multirow{2}{*}{$\underset{(-\log T)}{C_{0}}$} & \multicolumn{3}{|c|}{ In anaerobic condition } & \multicolumn{3}{|c|}{ In normal condition } \\
\hline & & & & $\begin{array}{c}\text { Time } \\
(\mathrm{hr})\end{array}$ & $\underset{\left(10^{3} / \mathrm{hr}\right)}{\mathrm{SFC}}$ & 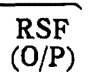 & $\begin{array}{l}\text { Time } \\
(\mathrm{hr})\end{array}$ & $\underset{\left(10^{8} / \mathrm{hr}\right)}{\mathrm{SFC}}$ & $\begin{array}{c}\text { RSP } \\
(0 / P)\end{array}$ \\
\hline 11 & & $0-$ & 0.9 & $0.5 \sim 10$ & 31.1 & 9.7 & $0 \sim 20$ & 31.5 & 6.8 \\
\hline 12 & & $p-$ & 1.5 & $0.5 \sim 10$ & 3.2 & & $0 \sim 20$ & 4.6 & \\
\hline 15 & & $0-$ & 1.0 & $0.5 \sim 10$ & 36.5 & 6.0 & $0 \sim 20$ & 37.7 & 2.8 \\
\hline 16 & & $p-$ & 1.0 & $0.5 \sim 10$ & 6.1 & & $0 \sim 20$ & 13.7 & \\
\hline
\end{tabular}

特異性現鿶であり，さきの退色機粠に侵先するニトロ基の光還元 の奇与が示唆される。

つぎに異常退色に括ける位圆特異性現象を検討するため，2-二 トロ $-4^{\prime}-(N, N$-ビス圆換アルキル)アミノー1, 1'-アソベンセン系 染料の退色挙㽖をポリエステルとポリフミドフィルム上に拈いて 調へ，対応する 4-ニトロ系染料のそれと比㬵した。この結果を

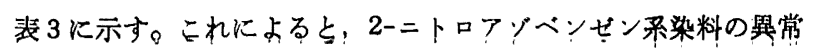

退色はポリェステル上とポリフミド上の双方にみられ，いずれの 系列においても 2-ニトロ体の耐光性が 4-ニトロ体にくらべ3倍 〜10 倍程度低下する。同様な退色挙動がセルロースアセテート やトリアセテート上にもみられる。このことはこの異常退色が基

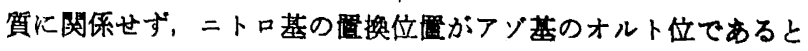
いら位直特異性現象であることを示唆する。たた，ポリエステル テルとポリアミドとの基筫による遍色举塹の㩆著な差異は 4-二 
Table 5 Fading parameter for some 2,4-dinitroazobenzenes in PE and PA film

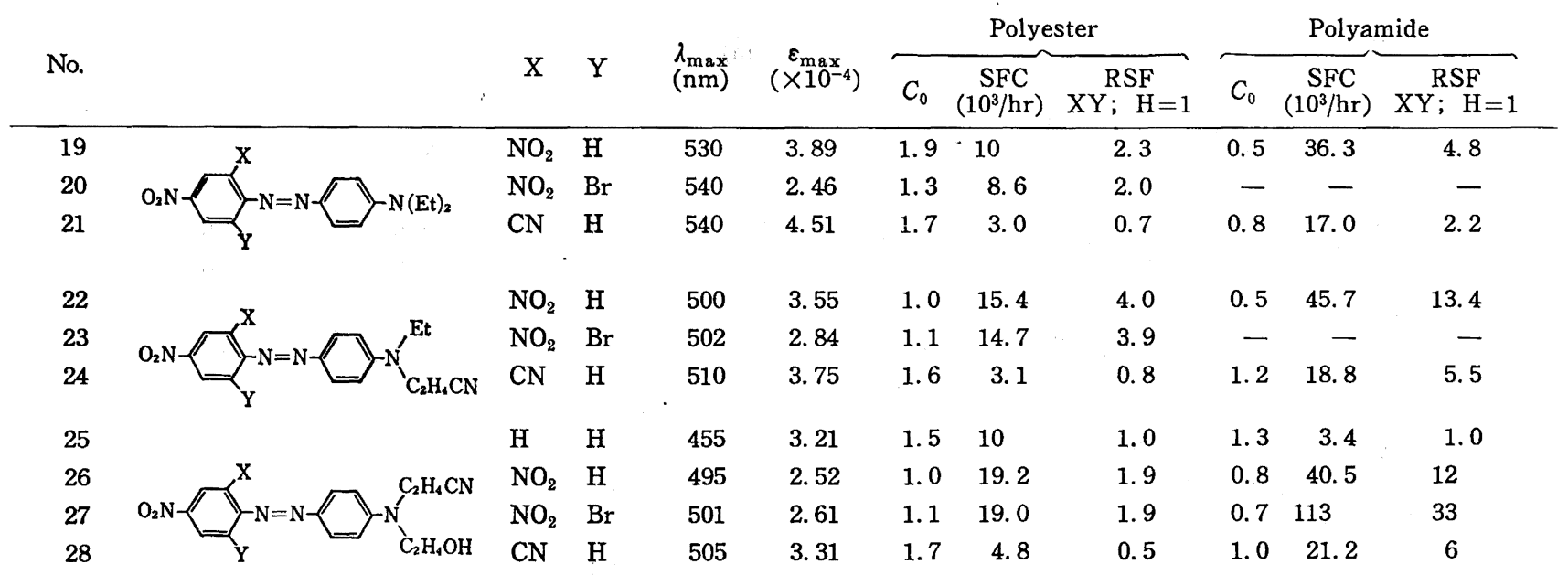

トロ-4'-(N,N-ビスシアノェチル)アミノ-1, 1'-アゾベンゼン (No.12) そみられる。これはこの化合物の色調からみてビスシフ ノェチルアミノ基の電子供与力はかなり小さいものと考えられる ので, ポリエステル上ではアゾ基の光酸化をらけにくく耐光性に すぐれるがポリアミド上ではニトロ基の光還元の寄与で特異的に 耐光性が低下することに起因しているように思われる。

さて，異常退色における位置特異性現象については とアゾ基との分子内酸化還元反応によるアゾキシ化の奇与が考兄 られる。すなわち，ある種のニトロ化合物が温和な酸化剂である ことや 0 -ニトロベンズアルデヒドの光照射で o-ニトロソ安息香 酸が高収率で得られる(6)てとが知られているらえに，0-ニトロ 基の酸素原子とアゾ基の $\beta$-窒素原子とは六員環を形成できる位 置関係にあるので, ニトロ基はニトロソ基に，そしてアゾ基はフ ゾキシ基にきわめて容易に分子内光酸化をらけやすく, 異常に速 く退色が進むるのと思われる。すしてうだすると，嫌気条件下 では 4-ニトロアゾヘンゼン系染料の退色がいくぶん抑制される であろらけれどる2-ニトロアゾベンゼン系染料の退色挙動はほ とんど変わらないはずである。そこで，いくぶん嫌気条件下にお ける退色挙動を二三の系列について検討し, 表 4 に示した。これ

6) P.A. Leighton, F. A. Lucy, J. Chem. Phys., 2, 756, 760 (1934).

7) J. N.Pitts, K.S. Wan, E. A. Schuck, J. Amer. Chem. Soc., 86, 3606(1964).
によると，予期のように，2-ニトロ体の退色挙動はこのような嫌 気条件下でるほとんど変わらないのに 4-ニトロ体の退色はいく ぶん抑制されているのが認められる。

最後に 2,4-ジニトロアゾベンゼン系染料の光退色挙動を調べ， 2,4-ジニトロ-6-ブロモアゾベンゼン系や 4-ニトロ-2-シアノア ゾベンゼン系のものと比較して表 5 に示した。これによると， 2,4-ジニトロアゾベンゼン系の耐光性はポリエステル上では 2ニトロ体と 4-ニトロ体のそれの中間に位するのに対しポリアミ ド上では 2-ニトロ体より低下している。また，2,4-ジニトロ-6-

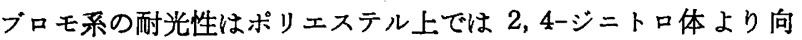
上するのに対しポリアミド上では逆に低下している。そして 4ニトロ-2-シアノ系の耐光性はポリエステル上では 4-ニトロ体よ り向上するのにポリアミド上では低下する。このことは, ポリエ ステル上では 0 -ニトロ基に起因する異常退色性が 2-ニトロ体か ら 2,4-ジニトロ体さらに 2,4-ジニトロー6-ブロモ体となるにし たがい（つまりアゾ基の電子密度が减少するにしたがい）抑制さ れることと,ポリアミド上では $p$-ニトロ基に起因する異常退色性 が 4-ニト口体から 4-ニトロ-2-シアノ体, 2,4-ジニトロ体, 2,4-ジニトロ-6-ブロモ体の順に（つまり，二トロ基の電子密度 が減少するにしたがい）加速されることを示し，さきの提案を支 持するように思われる。

(1971 年 10 月, 日本化学会第 25 秋季年会; 1972 年 6 月, 第 14 回染色化学討論会講演)

\title{
Contribution of Nitro Group on the Anomalous Photofading of Some Azo Disperse Dyes ${ }^{\dagger}$
}

\author{
Teijiro Kitao*, Yukio Watada*, Masaru Matsuoka* \\ and Kenzo KoNisHI \\ Department of Applied Chemistry, University of Osaka Prefecture; \\ Mozu-Umemachi, Sakai-shi 591 Japan
}

The behavior of photofading of some azo disperse dyes containing nitro group has been examined on polyester and on polyamide films. The contribution of nitro group on the anomalous photofading of these dyes was discussed. 4-Nitro-2'-hydroxy-, 4-nitro-4'-hydroxy, 4-nitro- $2^{\prime}, 4^{\prime}$-dihydroxy-and 4-nitro-4'-N, N-biscyanoethylaminoazobenzenes on polyamide fade by light easier than the corresponding 4-unsubsțtitututed derivatives. It is obṣerved that there 
is a correlation between the basicity of a dye and its sensitivity to the anomalous photofading. Anomolous fading of a dye proceeds easily when it is less basic, and 4 -nitro-4'-N, $N$-diethylaminoazobenzene does not show the character. The specific anomalous fading of 4-nitroazobenzenes on polyamide may be explained by the assumption that the nitro group can be photoreduced to amino group prior to photooxidation of azo group to azoxy group. 2-Nitroazobenzenes on polyester and on polyamide fade by light much more easily than the corresponding 4-nitro derivatives. In anaerobic condition, 4-nitroazobenzenes are more resitant to fading than that in normal condition, however, the fading of 2-nitro-azobenzenes does not change practically in both conditions. The anomalous fading of 2-nitroazobenzenes is position specific and may be explained by the assumption that intramolecular photo-oxidation of azo group to azoxy group proceeds exclusively by 2 -nitro group. The behavior of fading of 2 ,4-dinitroazobenzenes has also been examined and discussed.

$\dagger$ Photofading Reaction of Dyes. IV. 